\title{
Erosive rainfall in Rio do Peixe Valley in Santa Catarina, Brazil: Part I - Determination of the erosivity index
}

\author{
Álvaro J. Back ${ }^{1}$, Augusto C. Pola ${ }^{1}$, Nilzo I. Ladwig ${ }^{2}$ \& Hugo Schwalm ${ }^{3}$ \\ ${ }^{1}$ Empresa de Pesquisa Agropecuária e Extensão Rural de Santa Catarina/Estação Experimental de Urussanga. Urussanga, SC. E-mail: ajb@epagri.sc.gov.br \\ (Corresponding author); pola@epagri.sc.gov.br \\ ${ }^{2}$ Universidade do Extremo Sul Catarinense/Programa de Pós Graduação em Ciências Ambientais. Criciúma, SC. E-mail: ladwig@unesc.net \\ ${ }^{3}$ Universidade do Extremo Sul Catarinense/Departamento de Engenharia de Agrimensura. Criciúma, SC. E-mail: hsc@unesc.net
}

\section{Key words:}

soil loss

soil conservation

water erosion

precipitation

\begin{abstract}
A B S T R A C T
This study aimed to determine the rainfall erosivity index in the Valley of Rio do Peixe, in the state of Santa Catarina, Brazil. The data series of three rain gauge stations in the cities of Campos Novos, Videira, and Caçador were used to determine the rainfall erosivity based on the EI30 index and to adjust the equations in order to estimate the EI30 value from the rainfall coefficient. On average, it was observed that erosive rains represents $81.4-88.5 \%$ of the annual precipitation. The adjusted equations can be used to estimate rainfall erosivity in locations with only rainfall data. The regional equation specified for the erosivity estimation is $\mathrm{EI} 30=74.23 \mathrm{Rc}^{0.8087}$. The $\mathrm{R}$ factor is 8,704.8; 7,340.8; and 6,387.1 MJ mm ha $\mathrm{m}^{-1} \mathrm{~h}^{-1} \mathrm{year}^{-1}$ for Campos Novos, Videira, and Caçador, respectively. In Campos Novos and Videira, the erosivity was classified as high, while in Caçador, it was classified as average.
\end{abstract}

\section{Palavras-chave:}

perda de solos conservação do solo erosão hídrica precipitação

\section{Chuvas erosivas do Vale do Rio do Peixe: Parte I - Determinação do índice de erosividade}

\section{R E S U M O}

Este trabalho teve como objetivo determinar o índice de erosividade das chuvas para a região do Vale do Rio do Peixe, em Santa Catarina, Brasil. Foram usadas as séries de três estações pluviográficas para determinar a erosividade das chuvas baseado no índice EI30 e ajustar as equações para estimar o valor de EI30 a partir do coeficiente de chuva. Observouse que as chuvas erosivas representam em média de 81,4 a $88,5 \%$ da precipitação anual. As equações ajustadas podem ser usadas para estimar a erosividade da chuva em locais com somente dados pluviométricos, e a equação regional indicada para a estimativa da erosividade é EI30 = 74,23 Rc ${ }^{0,8087}$. O fator Ré de 8704,8, 7340,8 e 6387,1 MJ mm ha ${ }^{-1} \mathrm{~h}^{-1}$ ano $^{-1}$ respectivamente para Campos Novos, Videira e Caçador. Em Campos Novos e Videira a erosividade é classificada como Alta enquanto que em Caçador é classificada como Média. 


\section{INTRODUCTION}

Mathematical and hydrological modeling have been used to predict soil erosion losses, evaluate soil conservation practices, and assist in agricultural planning (Amorim et al., 2010; Kinnell, 2010). The Universal Soil Loss Equation (USLE) model is the most notable, and it includes the rainfall erosivity factor (R).

Several indices were developed to determine rainfall erosivity, including the EI30 index (Wischmeier \& Smith, 1978; Kinnell, 2010) and the KE > 25 index (Hudson, 1971; Morais et al. 1988). Carvalho et al. (1991) concluded that the equation for the calculation of kinetic energy does not differ significantly between those two indices. Morais et al. (1988), who studied the correlation of erosion with the loss of soil, stated that the EI30 index is considered to be the most adequate in the state of Rio Grande do Sul (RS) to estimate the erosive potential of rain.

Determining erosion of an individual rainfall is performed with the analysis of the pluviograms, which require a long series of data. Several authors comment on the difficulty of obtaining this data, both in Brazil and in other countries (Beskow et al., 2009; Mello et al., 2007). As a result, the most common method to use the average of the monthly and annual precipitation, which can be obtained based on rainfall records from rain gauges (Waltrick et al., 2015). This methodology is often used to estimate the annual erosivity and to generate erosivity maps, as done by Silva (2004), Oliveira et al. (2012) and Mello et al. (2013).

The objective of this study was to determine the Universal Soil Loss Equation (USLE) rainfall erosivity factor (R) by using the standard procedure based on pluviographic records and to adjust the equations to estimate the rainfall erosivity based on the rainfall data from the Valley of Rio do Peixe, in the state of Santa Catarina (SC), Brazil.

\section{Material ANd Methods}

Pluviographic data from three meteorological stations of the Company of Agricultural Research and Rural Extension of Santa Catarina (EPAGRI), located in the Valley of Rio do Peixe in the state of Santa Catarina, Brazil, were used for this study (Table 1). Daily pluviometric data were also used to obtain a series from the same period of observation because the pluviographic records have some missing data, and the series were not from the same period. According to the Köppen classification, the climate of the region is classified as humid and subtropical - without a dry season and with a mild summer (Cfb) (Alvares et al., 2014).

The hyetograph data (pluviograph data) were digitized. A computer program was developed to read the digitized data and to perform the calculations, as described by Valvassori \& Back (2014).
A pluviometric precipitation of $10 \mathrm{~mm}$ or more, or rain precipitation of $6 \mathrm{~mm}$ or greater over a maximum interval of $15 \mathrm{~min}$, is considered to be an erosive rain according to the criteria proposed by Wischmeier \& Smith (1958) and modified by Cabeda (1976). The calculation of the kinetic energy units of each uniform segment of rain used in this study was proposed by Wischmeier \& Smith (1978) and modified by Foster et al. (1981); this expression is as follows:

$$
\mathrm{EC}=0.119+0.0873 \log \mathrm{i}
$$

wherein the EC is the kinetic energy $\left(\mathrm{MJ} \mathrm{ha}^{-1} \mathrm{~mm}^{-1}\right)$; and $\mathrm{i}$ is the rainfall intensity - given in $\mathrm{mm} \mathrm{h}^{-1}$ in the segment under consideration.

For intensity greater than $76 \mathrm{~mm} \mathrm{~h}^{-1}$, the kinetic energy was considered equal to $0.283 \mathrm{MJ} \mathrm{ha}^{-1} \mathrm{~mm}^{-1}$ (Foster et al., 1981).

The kinetic energy of the segment, expressed in $\mathrm{MJ} \mathrm{ha}^{-1}$, is calculated by multiplying the EC by the amount of rainfall in the respective uniform segment, i.e.:

$$
\mathrm{ECs}=\mathrm{EC} \mathrm{h}
$$

wherein ECs is the kinetic energy of the segment $\left(\mathrm{MJ} \mathrm{ha} \mathrm{ha}^{-1}\right)$; and $h$ is the precipitation of the segment $(\mathrm{mm})$.

By summing up the kinetic energy of each uniform segment, the total kinetic energy of the rain is found, i.e.:

$$
\mathrm{ECt}=\sum \mathrm{ECs}
$$

The EI30 index, which represents the erosivity of each individual and erosive rainfall, is determined through the following expression, according to Cassol et al. (2007):

$$
\mathrm{EI} 30=\mathrm{ECt} \mathrm{I} 30
$$

wherein EI30 is the erosivity index of the individual erosive rainfall $\left(\mathrm{MJ} \mathrm{mm} \mathrm{ha-1} \mathrm{h}^{-1}\right)$; ECt is the total kinetic energy of rainfall $\left(\mathrm{MJ} \mathrm{ha}^{-1}\right)$; and $\mathrm{I} 30$ is the maximum 30 -minute intensity of storm $\left(\mathrm{mm} \mathrm{h}^{-1}\right)$.

The linear and potential relationships between the rainfall erosivity calculated by the EI30 Index and the rainfall coefficient were established from the values of the rainfall erosivity index and the monthly and annual rainfall by the following expressions:

$$
\begin{gathered}
\mathrm{EI} 30=\mathrm{a}+\mathrm{bRc} \\
\mathrm{EI} 30=\mathrm{aRc} c^{\mathrm{b}}
\end{gathered}
$$

\begin{tabular}{|c|c|c|c|c|c|}
\hline \multirow{2}{*}{ City } & \multirow{2}{*}{$\begin{array}{l}\text { Latitude } \\
\text { (S) }\end{array}$} & \multirow{2}{*}{$\begin{array}{l}\text { Longitude } \\
\text { (W) }\end{array}$} & \multirow{2}{*}{$\begin{array}{l}\text { Altitude } \\
\text { (m) }\end{array}$} & \multicolumn{2}{|c|}{ Period of data used } \\
\hline & & & & Pluviographic & Pluviometric \\
\hline Campos Novos & $28^{\circ} 24^{\prime}$ & $51^{\circ} 12^{\prime}$ & 952 & $01 / 1984$ to $12 / 2014$ & $01 / 1984$ to $12 / 2015$ \\
\hline Videira & $27^{\circ} 00^{\prime}$ & $51^{\circ} 09^{\prime}$ & 774 & $04 / 1985$ to $04 / 2015$ & $01 / 1984$ to $12 / 2015$ \\
\hline Caçador & $26^{\circ} 46^{\prime}$ & $51^{\circ} 00$ & 960 & $01 / 1984$ to $12 / 2014$ & $01 / 1984$ to $12 / 2015$ \\
\hline
\end{tabular}

wherein EI30 is the rainfall erosivity index $\left(\mathrm{MJ} \mathrm{mm} \mathrm{ha-1} \mathrm{h}^{-1}\right)$; a and $b$ are the coefficients of adjustment; and $\mathrm{Rc}$ is the rainfall coefficient in $\mathrm{mm}$, given by the following relation:

Table 1. Location of the stations with the respective periods of the data used, in the state of Santa Catarina, Brazil 


$$
\mathrm{Rc}=\frac{\mathrm{Pm}^{2}}{\mathrm{~Pa}}
$$

wherein $\mathrm{Pm}$ is the average monthly rainfall; and $\mathrm{Pa}$ is the average annual rainfall in $\mathrm{mm}$.

The values of EI30 were estimated for the data series of the respective rain gauges of each station by using the adjusted equations, and also a general equation with the data from the four seasons.

\section{RESUlts AND Discussion}

In the rainfall data series from the Campos Novos station, an average of $1,790 \mathrm{~mm}$ of precipitation was recorded, and $81.4 \%$ of the precipitation was classified as erosive rain (Table 2). In Videira, the average precipitation was $1,765.7 \mathrm{~mm}$ with $82.2 \%$ erosive rains; while, in the Caçador Station, the average rainfall was $1,482.6 \mathrm{~mm}$, and $88.5 \%$ classified as erosive rains. The lower values of precipitation observed in Caçador can be partly explained by greater missing pluviographic data. According to Alvares et al. (2014), in Campos Novos, Videira, and Caçador, the average annual precipitation measured with pluviometric rain gauges is 1,$704 ; 1,730$; and $1,738 \mathrm{~mm}$; respectively. Similar percentage values of erosive rains were obtained by Back et al. (2016), who analysed pluviographic data from Chapecó SC, and by Valvassori \& Back (2014), who analysed pluviographic data from Urussanga SC.

Precipitation ranged from 2,547.2 in 1990 to $1,229.0 \mathrm{~mm}$ in 2004 in Campos Novos (Figure 1A), while EI30 values ranged from 4,292.5 in 1984 to $11,711.6 \mathrm{MJ} \mathrm{mm} \mathrm{ha}^{-1} \mathrm{~h}^{-1}$ in 1998 . Similar variations were observed in Videira (Figure 1B). However, in Caçador (Figure 1C), the precipitation vary from 2,164 in 1997 to $948.2 \mathrm{~mm}$ in 2003, and the EI30 ranged from 2,484.1 in 2004 to $10,219.0 \mathrm{MJ} \mathrm{mm} \mathrm{ha}{ }^{-1} \mathrm{~h}^{-1}$ in 2014 . It is observed that there is a direct correlation between the precipitation and the EI30 index, but the total precipitation does not fully explain the erosivity variation. There are years with similar values for total annual precipitation, but with differences greater than $20 \%$ in EI30 values, as observed in the years 1992, 2005, and 2007 (Figure 1A). This finding is explained by the fact that erosivity depends not only on the total precipitated rain, but mainly on

Table 2. Mean monthly rainfall and erosive rains measured by rain gauge stations in the Valley of Rio do Peixe in the state of Santa Catarina, Brazil

\begin{tabular}{|c|c|c|c|c|c|c|}
\hline \multirow[b]{2}{*}{ Period } & \multicolumn{2}{|c|}{ Campos Novos } & \multicolumn{2}{|c|}{ Videira } & \multicolumn{2}{|c|}{ Caçador } \\
\hline & $\begin{array}{l}\text { Total } \\
\text { (mm) }\end{array}$ & $\begin{array}{c}\text { Erosive } \\
(\%)\end{array}$ & $\begin{array}{l}\text { Total } \\
\text { (mm) }\end{array}$ & $\begin{array}{c}\text { Erosive } \\
(\%)\end{array}$ & $\begin{array}{l}\text { Total } \\
\text { (mm) }\end{array}$ & $\begin{array}{c}\text { Erosive } \\
(\%)\end{array}$ \\
\hline Jan & 175.5 & 80.2 & 184.8 & 84.7 & 152.8 & 83.7 \\
\hline Feb & 153.1 & 77.6 & 169.9 & 83.1 & 128.7 & 83.2 \\
\hline Mar & 123.7 & 72.5 & 123.5 & 78.0 & 103.0 & 82.3 \\
\hline Apr & 155.3 & 83.3 & 130.1 & 79.9 & 108.1 & 89.5 \\
\hline May & 156.5 & 72.7 & 135.3 & 86.3 & 106.6 & 96.1 \\
\hline Jun & 144.4 & 62.7 & 130.0 & 71.3 & 110.4 & 94.7 \\
\hline Jul & 137.1 & 71.9 & 123.9 & 85.7 & 109.5 & 94.3 \\
\hline Aug & 121.7 & 86.7 & 100.0 & 87.0 & 93.1 & 87.4 \\
\hline Sep & 171.7 & 88.2 & 176.2 & 88.0 & 161.6 & 89.9 \\
\hline Oct & 202.8 & 89.0 & 193.3 & 80.7 & 174.9 & 89.2 \\
\hline Nov & 129.0 & 80.9 & 137.0 & 80.2 & 113.9 & 84.6 \\
\hline Dec & 133.4 & 75.4 & 161.6 & 81.8 & 120.1 & 87.4 \\
\hline Year & 1790.0 & 81.4 & 1765.7 & 82.2 & 1482.6 & 88.5 \\
\hline
\end{tabular}

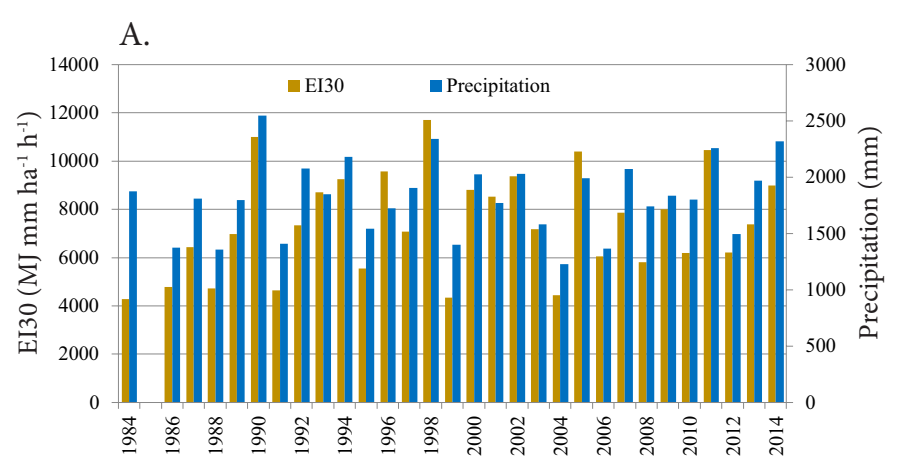

B.

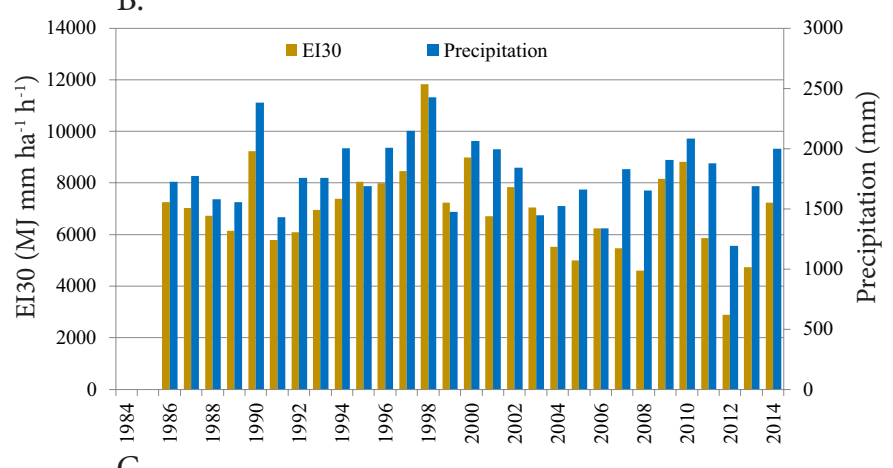

C.

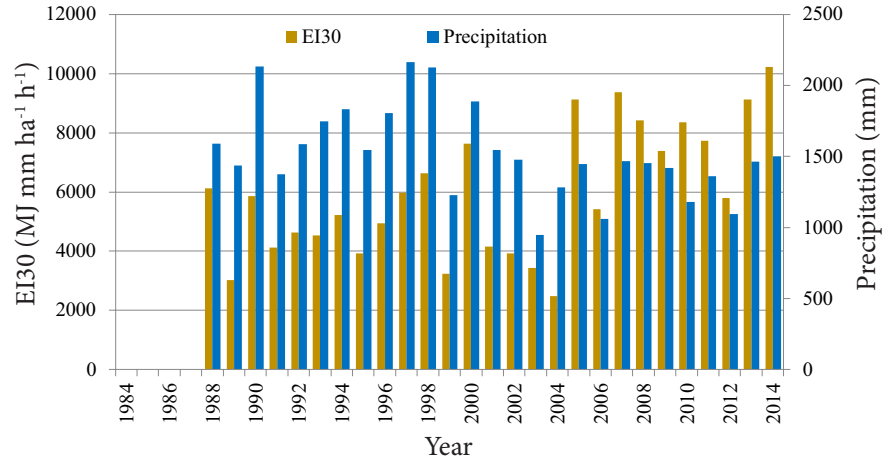

Figure 1. Annual rainfall values and EI30 index for Campos Novos (A), Videira (B), and Caçador (C) in the state of Santa Catarina, Brazil

the intensity of the rainfall. Another important observation in Figure 1 is that there is a large variation of rainfall erosivity; therefore, using an annual average value - which is used in many models to predict soil losses - may not be the best way to represent the soil losses over a long period of time.

According to Schick et al. (2014), the estimation of the erosivity index, especially its cumulative distribution over time, allows researchers to identify the time of year with the highest risk of water erosion; this helps to create a plan to control the water erosion more efficiently.

In the analysed stations, similar behaviors were observed. From January to March, the EI30 percentage values were slightly higher than the percentage values of precipitation. On the other hand, in the winter months from June to August, the opposite occured (Figure 2). However, the differences in monthly percentage values are less than $5 \%$.

In Campos Novos (Figure 2A) from January to March, $25.1 \%$ rainfall and $29.70 \%$ EI30 values occurred, and in Videira, these values were 27.1 and $34.9 \%$, respectively (Figure 2B). In Caçador (Figure 2C), a nearly uniform distribution of precipitation and EI30 values were observed. Valvassori \& Back (2014) and Back et al. (2016) had already reported this 

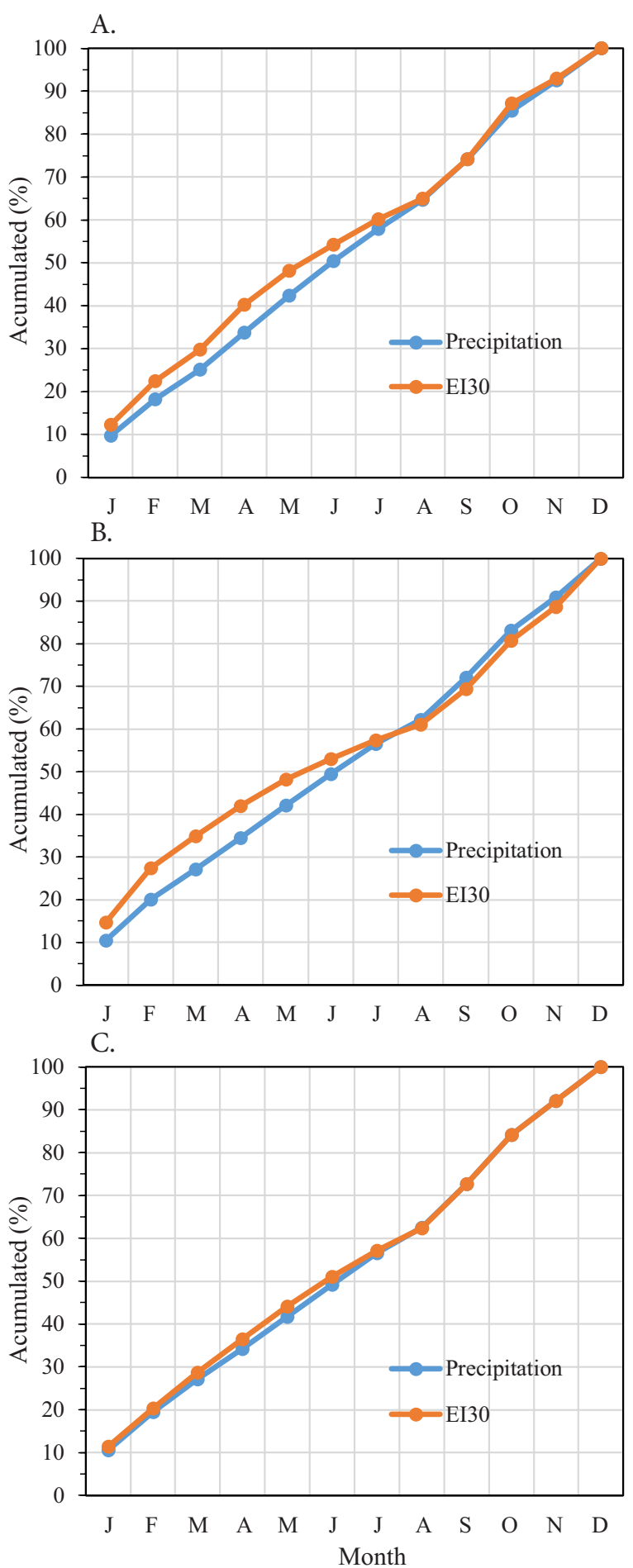

Figure 2. Cumulative rainfall distribution and erosivity for Campos Novos (A), Videira (B) and Caçador (C) in the state of Santa Catarina, Brazil

uniformity in rainfall distribution and erosivity index in rain gauge stations in Santa Catarina.

However, in some Brazilian regions, there is a marked seasonal variation in erosivity. Almeida et al. (2012) reported a proportion equal to or greater than $94 \%$ erosivity occurring in the spring and summer seasons. Lombardi Neto (1977) found that $90.7 \%$ of the erosivity index was from October to March, when the rainfall is at $80.1 \%$ of the total annual precipitation in the city of Campinas, in the state of São Paulo (SP). In Santa Catarina, especially in the Valley of Rio do Peixe, rainfall is well distributed throughout the year, so there is less seasonal variation in the rainfall erosivity indices. Therefore, it is important to note that conservation practices of erosion control must be adopted throughout the year.
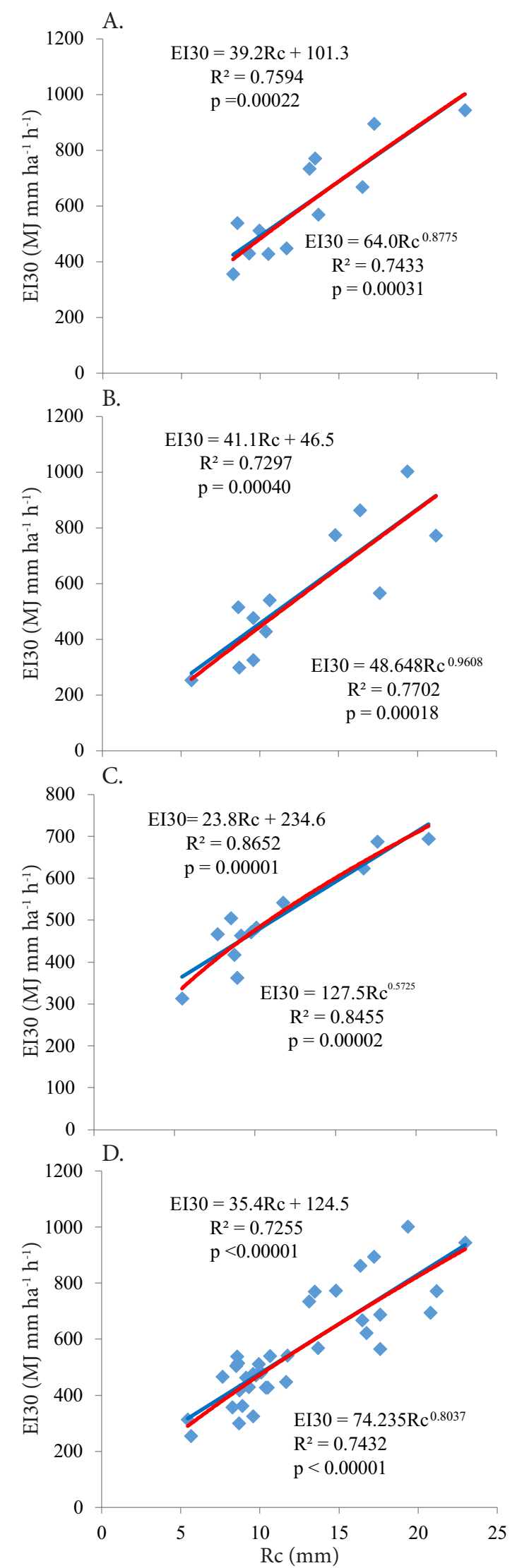

Figure 3. Regression between erosivity index (EI30) and rainfall coefficient (Rc) for Campos $\operatorname{Novos}(A)$, Videira (B), Caçador (C), and for the Valley of Rio do Peixe in (D) in the state of Santa Catarina, Brazil 
Table 3. Data of the estimated monthly precipitation $(\mathrm{mm})$ and erosivity index (EI30) in the state of Santa Catarina, Brazil

\begin{tabular}{|c|c|c|c|c|c|c|c|c|c|c|c|c|}
\hline \multirow{2}{*}{ Period } & \multicolumn{4}{|c|}{ Campos Novos } & \multicolumn{4}{|c|}{ Videira } & \multicolumn{4}{|c|}{ Caçador } \\
\hline & Precipitation & El30 & $\mathrm{El} 30^{2}$ & $\mathrm{El} 3 \mathrm{O}^{3}$ & Precipitation & $\mathrm{El}^{3} 0^{1}$ & $E \mid 30^{2}$ & $E 130^{3}$ & Precipitation & $\mathrm{El}^{3} 0^{1}$ & $\mathrm{El} 30^{2}$ & $\mathrm{El} 3 \mathrm{O}^{2}$ \\
\hline Jan & 208.1 & 895.7 & 935.2 & 877.6 & 194.81 & 1003.1 & 861.0 & 826.0 & 184.2 & 687.5 & 700.6 & 817.6 \\
\hline Feb & 181.5 & 734.5 & 736.2 & 697.8 & 180.57 & 863.3 & 746.3 & 727.2 & 155.8 & 542.3 & 568.0 & 620.4 \\
\hline Mar & 136.3 & 538.5 & 459.0 & 447.5 & 132.38 & 515.8 & 422.6 & 448.4 & 121.7 & 504.4 & 437.8 & 426.8 \\
\hline Apr & 167.1 & 771.1 & 639.0 & 610.1 & 142.89 & 477.3 & 484.7 & 501.9 & 115.5 & 467.1 & 417.9 & 397.1 \\
\hline May & 172.5 & 568.5 & 674.7 & 642.4 & 131.18 & 427.9 & 415.8 & 442.6 & 125.1 & 463.8 & 449.5 & 444.2 \\
\hline Jun & 171.4 & 448.6 & 667.5 & 635.8 & 150.51 & 325.6 & 532.7 & 543.3 & 138.3 & 417.7 & 497.2 & 515.0 \\
\hline Jul & 170.1 & 428.5 & 658.8 & 627.9 & 135.76 & 299.3 & 442.1 & 465.2 & 119.9 & 362.4 & 432.1 & 418.2 \\
\hline Aug & 136.7 & 356.5 & 461.2 & 449.5 & 113.14 & 254.1 & 321.3 & 361.1 & 101.2 & 313.3 & 375.3 & 333.8 \\
\hline Sep & 216.7 & 668.8 & 1006.2 & 941.7 & 190.06 & 565.6 & 821.8 & 792.3 & 167.9 & 623.4 & 621.7 & 700.3 \\
\hline Oct & 244.7 & 944.6 & 1254.5 & 1165.9 & 215.13 & 771.8 & 1039.8 & 980.0 & 200.3 & 694.5 & 785.4 & 943.8 \\
\hline Nov & 153.7 & 429.1 & 556.2 & 535.3 & 158.26 & 540.4 & 584.1 & 587.5 & 144.1 & 482.0 & 519.7 & 548.6 \\
\hline Dec & 169.7 & 511.3 & 656.3 & 625.7 & 170.26 & 773.7 & 668.7 & 660.4 & 159.0 & 471.7 & 581.7 & 640.8 \\
\hline Year & 2034.9 & 7295.6 & 8704.8 & 8257.2 & 1914.9 & 6817.9 & 7340.8 & 7336.1 & 1732.9 & 6030.1 & 6387.1 & 6806.8 \\
\hline
\end{tabular}

${ }^{1}$ El30 determined by the standard procedure based on pluviographic records; ${ }^{2}$ El30 index values estimated with the equation adjusted for the station; ${ }^{3}$ El30 index values estimated with the regional equation

A better fit was obtained with the linear model for the stations of Campos Novos $\left(\mathrm{R}^{2}=0.7594\right)$ (Figure $3 \mathrm{~A}$ ) and Caçador $\left(R^{2}=0.8652\right)$ (Figure $3 C$ ), while the potential model showed better fit for the Videira data $\left(R^{2}=0.7702\right)$ (Figure $3 B$ ) and for the regional equation $\left(R^{2}=0.7432\right)$ (Figure 3D). However, both linear and potential models were significant ( $\mathrm{p}<0.001)$ and can be used. This is confirmed by the small difference in the determination coefficient values and also by the superposition of the potential model curves with the regression lines (Figure 3).

Table 3 shows the average values of precipitation observed in the rain gauges of each station and the respective EI30 index values estimated with the equation adjusted for the station $\left(\mathrm{EI} 30^{1}\right)$ and with the regional equation $\left(\mathrm{EI} 30^{2}\right)$. The differences between those estimates were $5.4 \%$ in Campos Novos, $0.1 \%$ in Videira, and $6.6 \%$ in Caçador; this reinforces the validity of using the regional equation in the estimation of EI30 indices for the Valley of Rio do Peixe in Santa Catarina.

The average annual EI30 values represent the erosivity index (R factor) of the Universal Soil Loss Equation (Kinnell, 2010). The $\mathrm{R}$ factor is 8,704.8 MJ mm ha ${ }^{-1} \mathrm{~h}^{-1}$ year $^{-1}$ in Campos Novos; 7,340.8 MJ mm ha ${ }^{-1} \mathrm{~h}^{-1}$ year-1 in Videira; and 6,387.1 MJ mm ha ${ }^{-1} \mathrm{~h}^{-1}$ year $^{-1}$ in Caçador. According to Santos (2008), $R$ values between 5,000 and 7,000 MJ mm ha- $\mathrm{h}^{-1}$ year-1 indicate an average erosivity, and values between 7,000 and 10,000 MJ mm ha- ${ }^{-1} \mathrm{~h}^{-1}$ year ${ }^{-1}$ indicate a high erosivity. Lombardi Neto (1977) obtained the EI30 average erosivity index of 6,769 MJ mm ha- $\mathrm{h}^{-1}$ year ${ }^{-1}$ for Campinas SP. These values are consistent with other erosivity studies performed in Brazil.

Eltz et al. (2013) calculated the E130 erosivity index for the city of São Gabriel RS, and found average values of 6,432 MJ mm ha ${ }^{-1} h^{-1}$ year ${ }^{-1}$. Valvassori \& Back (2014) analysed the recorded values in the rain gauges from Urussanga, located in southern Santa Catarina, and found $\mathrm{R}$ values of 5,665 MJ mm ha ${ }^{-1} h^{-1}$ year ${ }^{-1}$. Back et al. (2016) analysed a series of 39 years of pluviographic data from the city of Chapecó, SC, and found average erosivity of 9,045.0 MJ mm ha- $\mathrm{m}^{-1}$ year $^{-1}$. Other studies on erosivity for Santa Catarina were performed by Bertol (1993), who found an R value of 5,033 MJ mm ha ${ }^{-1} \mathrm{~h}^{-1} \mathrm{year}^{-1}$. It should be noted that in Lages and Urussanga, the average annual precipitation is less than $1,700 \mathrm{~mm}$, which is less in comparison to the Western and Midwestern regions of the state. This fact partly justifies the lower values of erosivity.

\section{Conclusions}

1. The erosivity index presents an annual and large variation while remaining proportional to the total precipitation.

2. The accumulated distribution of erosivity and precipitation throughout the year present similar variations, but with differences in monthly percentages below $5 \%$.

3. The adjusted equations to determine the EI30 index are significant in both the linear and potential models. They can be used to estimate the erosivity index based on observations of rain gauge stations in the region.

4. In the cities of Campos Novos and Videira, the erosivity is classified as high; and in Caçador, the erosivity is classified as average.

\section{ACKNOWLedgments}

The authors thank the Brazilian National Council for Scientific and Technological Development (CNPq) for the financial support to this research.

\section{Literature Cited}

Almeida, C. O. S.; Amorim, R. S. S.; Eltz, F. L. F.; Couto, E. G.; Jordani S. A. Erosividade da chuva em municípios do Mato Grosso: Distribuição sazonal e correlações com dados pluviométricos. Revista Brasileira de Engenharia Agrícola e Ambiental, v.16, p.142152, 2012. https://doi.org/10.1590/S1415-43662012000200003

Alvares, C. A.; Stape, J. L.; Sentelhas, P. C.; Gonçalves, J. L. de M.; Sparovek, G. Köppen's climate classification map for Brazil. Meteorologische Zeitschrift, v.22, p.711-728, 2014. https://doi. org/10.1127/0941-2948/2013/0507

Amorim, R. S. S.; Silva, D. D. da; Pruski, F. F.; Matos, A. T. de. Avaliação do desempenho dos modelos de predição da erosão hídrica USLE, RUSLE e WEPP para diferentes condições edafoclimáticas do Brasil. Engenharia Agrícola, v.30, p.1046-1049, 2010. https://doi. org/10.1590/S0100-69162010000600006

Back, A. J.; Alberton, J. V.; Poleto, C. Avaliação da erosividade das chuvas de Chapecó, Santa Catarina. In: Simpósio sobre Sistemas Sustentáveis, 3, 2016, Porto Alegre. Anais... Porto Alegre: ABRH, 2016. p.1-6.

Bertol, I. Índice de erosividade (EI30) para Lages (SC) - 1. aproximação. Pesquisa Agropecuária Brasileira, v.28, p.515-21, 1993. 
Beskow, S.; Mello, C. R.; Norton, D. L.; Curi, N.; Viola, M. R.; Avanzi, J. C. Soil erosion prediction in the Grande River Basin, Brazil using distributed model. Catena, v.79, p.49-59, 2009. https://doi. org/10.1016/j.catena.2009.05.010

Cabeda, M. S. V. Computation storm EI values. West Lafayette: Purdue University, 1976. 6p.

Carvalho, M. de P. E.; Lombardi Neto, F.; Vasques Filho, J.; Catâneo, A. Correlação entre o índice de erosividade EI30 médio mensal e o coeficiente de chuva do município de Mococa-SP. Científica, v.19, p.1-7, 1991.

Cassol, E. A.; Martins, D.; Eltz, F. L. F.; Lima, V. S. de; Bueno, A. C. Erosividade e padrões hidrológicos das chuvas de Ijuí (RS) no período de 1963 a 1993. Revista Brasileira de Agrometeorologia, v.15, p.220-231, 2007.

Eltz, F. L. F.; Cassol, E. A.; Pascotini, P. B.; Amorim, R. S. S. Potencial erosivo e características das chuvas de São Gabriel, RS, de 1963 a 1993. Revista Brasileira de Engenharia Agrícola e Ambiental, v.17, p.647-654, 2013. https://doi.org/10.1590/S141543662013000600011

Foster, G. R.; McCool, D. K.; Renard, K. G.; Moldenhauer, W. C. Conversion of the universal soil loss equation to SI metric units. Journal of Soil and Water Conservation, v.36, 355-359, 1981.

Hudson, N. Soil conservation. Ithaca: Cornell University Press, 1971. $320 \mathrm{p}$.

Kinnell, P. I. A. Event soil loss, runoff and the universal soil loss equation family of models: A review. Journal of Hydrology, v.385, p.384-397, 2010. https://doi.org/10.1016/j.jhydrol.2010.01.024

Lombardi Neto, F. Rainfall erosivity - Its distribution and relationship with soil loss at Campinas, Brazil. West Lafayette: Purdue University, 1977. 53p.

Mello, C. R. de; Sá, M. A. C. de; Curi, N.; Mello, J. M. de; Viola, M. R.; Silva, A. M. da. Erosividade mensal e anual da chuva no Estado de Minas Gerais. Pesquisa Agropecuária Brasileira, v.42, p.537545, 2007. https://doi.org/10.1590/S0100-204X2007000400012
Mello, C. R. de; Viola, M. R.; Beskow, S.; Norton, L. D. Multivariate models for annual rainfall erosivity in Brazil. Geoderma, v.202-203, p.88-102, 2013. https://doi.org/10.1016/j.geoderma.2013.03.009

Morais, L. F. B.; Mutti, L. S. M.; Eltz, F. L. F. Índices de erosividade correlacionados com perdas de solo no Rio Grande do Sul. Revista Brasileira de Ciência do Solo, v.12, p.281-284, 1988.

Oliveira, P. T. S.; Wendland, E.; Nearing, M. A. Rainfall erosivity in Brazil: A review. Catena, v.100, p.139-147, 2012. https://doi. org/10.1016/j.catena.2012.08.006

Santos, C. N. El Niño, La Niña e a erosividade das chuvas no estado do Rio Grande do Sul. Pelotas: UFPel, 2008. 138p. Tese Doutorado

Schick, J.; Bertol, I.; Cogo, N. P.; González, A. P. Erosividade de chuvas em Lages, Santa Catarina. Revista Brasileira de Ciência do Solo, v.38, p.1890-1905, 2014. https://doi.org/10.1590/S010006832014000600024

Silva, A. M. da. Rainfall erosivity map for Brazil. Catena, v.57, p.251259, 2004. https://doi.org/10.1016/j.catena.2003.11.006

Valvassori, M. L; Back, A. J. Avaliação do potencial erosivo das chuvas em Urussanga, SC, no período de 1980 a 2012. Revista Brasileira de Ciência do Solo, v.38, p.1011-1019, 2014. https:// doi.org/10.1590/S0100-06832014000300033

Waltrick, P. C.; Machado, M. A. de M.; Dieckow, J.; Oliveira, D. de. Estimativa da erosividade de chuvas no estado do Paraná pelo método da pluviometria: Atualização com dados de 1986 a 2008. Revista Brasileira de Ciência do Solo, v.39, p.256-267, 2015. https://doi.org/10.1590/01000683rbcs20150147

Wischmeier, W. H.; Smith, D. D. Rainfall energy and its relationship to soil loss. Earth \& Space Science News, v.39, p.285-291, 1958. https://doi.org/10.1029/TR039i002p00285

Wischmeier, W. H.; Smith, D. D. Predicting rainfall erosion losses: A guide to conservation planning. Hyattsville: USDA, Science and Education Adminstration, 1978. 62p. U.S Department of Agriculture Handbook, v.537 